\title{
Hypertension in Adolescent
}

\author{
Nataša Marčun Varda \\ Department of Pediatrics, University Medical Center Maribor, Maribor, Slovenia \\ Email: natasa.marcunvarda@amis.net
}

Received 22 July 2016; accepted 21 August 2016; published 24 August 2016

Copyright (C) 2016 by author and Scientific Research Publishing Inc.

This work is licensed under the Creative Commons Attribution International License (CC BY).

http://creativecommons.org/licenses/by/4.0/

c) (7) Open Access

\section{Abstract}

Hypertension in adolescents is, as in other patients, one of the important cardiovascular risk factors, associated with hypertension in adults and with appearance of cardiovascular complications later in life. In recent years it is in increase, in parallel with occurrence of overweight in this age group. There is mostly essential or obesity-related hypertension. It is often asymptomatic, therefore it holds true also for adolescents, that it has to be actively searched, especially in risk groups such as overweight adolescents, adolescents with positive family history or some of the other classical cardiovascular risk factors. If we have normal-weight adolescent with important hypertension or symptomatic adolescent without positive family history, the possibility of secondary hypertension has to be thinking of and extended, on possible cause focused and stepwise diagnostics performed. In this case, the treatment is etiological. Otherwise, the first-line treatment in adolescents comprises nonpharmacological treatment measures. Sometimes, because of poor nonpharmacological treatment compliance and presence of hypertensive-target organ damage, antihypertensive medications have to be introduced. However, preventive actions represent the most important task, in the form of primary and primordial prevention. In this article, diagnostic approach, prevention and treatment strategies in adolescents are shortly presented.

\section{Keywords}

Hypertension, Diagnostic Approach, Prevention, Treatment, Adolescent

\section{Introduction}

Hypertension is one of the most common chronic diseases in children, especially in adolescents [1]. In recent years, it has been increased, mainly due to a rise of obesity, having a significant impact on the level of blood pressure [BP] [2]. Thus, in one study of schoolchildren overweight has been observed in $27.9 \%$, increased BP in $18.4 \%$, and persistently elevated BP in $2.8 \%$ of included patients [3]. In American adolescents prehypertension or hypertension were observed in $14 \%$, which is an important part of adolescents at risk [1]. In adolescents with the single measurement of BP in pre-hypertensive range, after two years hypertension was confirmed in $14 \%$ of 
boys and $12 \%$ of girls [4]. It has been assessed that the rate of progression from prehypertension to hypertension in adolescents is 7\% annually [4]. In our population of adolescents with essential hypertension, we also found a link with overweight, as $42 \%$ of the subjects were overweight and $23 \%$ obese, respectively [5]. Many other studies have clearly demonstrated that hypertension also occurs in children, especially in obese, and that it is not rare [6]. Moreover, there is increasing evidence that it is associated with the development of hypertension and the occurrence of cardiovascular complications in adulthood, although we still do not have prospective study that would directly demonstrate the connection between hypertension in childhood and cardiovascular events later in life [7]-[10].

In pediatrics, American recommendations for management of children and adolescents with hypertension have been published in 2004 and European ones in 2009, both needing the revision [11] [12]. They cover both the normative values as well as algorithms for diagnosis and treatment. A few years ago, our recommendations for the diagnostic approach to the child with hypertension have also been published [13]. We must be aware that adolescents with cardiovascular risk, which include adolescents with elevated BP, have to be actively searched, since they are generally asymptomatic. These also often apply to young people who have a significant increase in BP values and most likely secondary hypertension [11]-[13]. At the same time, we have to take the principles of BP measurement into account using the appropriate devices and cuffs, normative values according to gender, age and height of the adolescent, reproducibility of measurements and evidence of sustained hypertension. These has to be followed by the decision about focused etiological diagnostics, and afterwards the determination of traditional cardiovascular risk factors, co-morbidity status, hypertensive target organ damage and total cardiovascular risk score have to be performed in all young hypertensive patients [12] [13]. Based on all these findings the decision about the proper therapy has to be made, which is primarily non-pharmacological. When cardiovascular risk is determined even in adolescents the medications are introduced, mostly angiotensin-converting enzyme (ACE) inhibitors and calcium channel antagonists [14]. At least, as important as treatment, our work in the field of prevention of cardiovascular diseases should start in childhood [15] [16].

\section{Definition of Hypertension in Adolescent}

The most important step in the search for adolescents with hypertension is correct measurement of BP [11] [12]. BP devices must be techically approved and the measurements made by protocol [12]. The cuff size has to be adapted to growth and development of adolescents and obesity if present. Therefore, even in individuals of the same age it may be different and should cover two-thirds of upper arm [11]. If measurement using the oscillometric method of BP measurement is performed it must be confirmed with auscultatory one, with calibrated devices [12] [17]. Another problem is the mercury device which is practically no longer produced in Europe, which necessitates the use of oscillometric devices. One important objective is to develop new exact BP devices and devices appropriate normative values [12]. Most reference values for children and adolescents, gained on large samples of included subjects, were carried out using the auscultatory method, and with the increasing use of oscillometric devices the reference values for them are needed. Some of the latter have already been published [18] [19].

Furthermore, it is important to use the reference values according to gender, age and height of the child and adolescent, the definition of hypertension in children and adolescents (Table 1) and to confirm persistently elevated BP [11] [12]. Diagnostic criteria for adolescents, as well as for children, are based on percentile curves, obtained by measuring BP of healthy population and define the increased BP as a systolic and/or diastolic BP above the 95th percentile for gender, age and height, measured at least at three different occasions [11]. Because we treat adolescents, it is also necessary to know the definition of hypertension for the adult population. According to the latest recommendations the high-normal BP for adults is in the range of 130 - 139 and/or 85/89 $\mathrm{mmHg}$, and hypertension, which has 3 stages, above the value of 140/90 $\mathrm{mmHg}$. Recommendations also use optimal BP, which is below 120/80 mmHg [20]. The recommendations for children and adolescents also define high normal BP, which is more than 120/80 mmHg, and hypertension with 2 stages (Table 1) [12]. In this light it is interesting to look at the results of one of the studies investigating the incidence of hypertension in 18-year old adolescents using adult criteria versus pediatric percentile curves. It was found that in the first case, the hypertension was 9\%, and in the second one, 14.7\% [21]. Table 1 shows the frequency of follow-up of adolescents at each hypertension stage [11] [12]. In recent years, 24-hour ambulatory BP measurement has also been increasingly used with reference values for this form of measurement [22] [23]. This is especially useful in 
Table 1. Definition of elevated blood pressure (BP) in children and adolescents and recommendation for follow-up measurements and diagnostic approach [11] [12].

\begin{tabular}{|c|c|c|}
\hline BP, hypertension & $\begin{array}{l}\text { Percentiles of systolic and/or } \\
\text { dyastolic BP }\end{array}$ & $\begin{array}{l}\text { Follow-up measurements of BP } \\
\text { and diagnostic approach }\end{array}$ \\
\hline Normal BP & $<90^{\text {th }}$ percentile & $\begin{array}{l}\text { During routine systematic and other } \\
\text { pediatric examinations }\end{array}$ \\
\hline High-normal BP & $\begin{array}{l}\quad \geq 90^{\text {th }} \text { to }<95^{\text {th }} \text { percentile } \\
\geq 120 / 80 \text {, in adolescents, even if the } \\
\text { value of BP is bellow } 90^{\text {th }} \text { percentile }\end{array}$ & After 6 months \\
\hline Stage 1 hypertension & $\begin{array}{c}\text { Between } 95^{\text {th }} \text { and } 99^{\text {th }} \text { percentile } \\
\text { plus } 5 \mathrm{mmHg}\end{array}$ & $\begin{array}{l}\text { After } 1 \text { to } 2 \text { weeks or before, if the } \\
\text { patient is symptomatic; if the BP is } \\
\text { persistently elevated, diagnostics has } \\
\text { to be performed in } 1 \text { month }\end{array}$ \\
\hline Stage 2 hypertension & $>99^{\text {th }}$ percentile plus $5 \mathrm{mmHg}$ & $\begin{array}{l}\text { Diagnostics and treatment in } \\
1 \text { week or immediately, if the } \\
\text { patient is symptomatic }\end{array}$ \\
\hline
\end{tabular}

determining white coat hypertension and masked hypertension, to monitor the effectiveness of pharmacological treatment and BP variability as well as in research purposes [22]. There is evidence that it better predicts cardiovascular events and the risk of target organ damage as the standard methods of measurement [24] [25].

\section{Diagnostic Evaluation of Hypertension in Adolescent}

Since the recommendations for BP measurements from the third year of age as a part of the routine preventive management of all children, it is possible to actively search for children at risk and thus adolescents, which are often, with significant hypertension, completely asymptomatic [11] [12]. When in adolescent persistently elevated BP is confirmed, he is classified, according to the clinical features, into one of two groups of patients. Most young people belong to the group of patients with mildly elevated BP, who are mostly asymptomatic, without changes in hypertensive target organs and the possible cardiovascular complications later in life [13]. These are adolescents with essential hypertension or obesity-related hypertension. Sometimes, even in this group a clinical suspicion of one of the secondary forms of hypertension is made, especially if we are dealing with a normally nourished, symptomatic adolescent with significant hypertension and a negative family history of cardiovascular diseases. The most common causes of elevated BP in adolescent patients are essential hypertension, and obesity-related hypertension, but iatrogenic causes, consumption of certain food supplements and drugs, renal parenchymal disease, renal vascular disease, endocrine causes and coarctation of the aorta can be diagnosed as well [11]-[13]. Most of them should be suspected with accurate history and good clinical examination [26]. Diagnostics must be stepwise [26]. Most adolescents need only investigations of Step 1, which are performed in all patients (routine tests) (Figure 1) [12]. They are needed for hypertensive target organ damage and traditional cardiovascular risk factors determination. Consideration should be given to concomitant diseases and the cardiovascular risk evaluation [12] [13]. Hypertensive target organ damage status is one of the important parts of the diagnostics, as it gives us insight into the initial effects of hypertension in adolescents, but also serves as an intermediate objective of successful treatment monitoring [12] [27]. Investigations of recent years show that the initial damage of target organs is present more often than it has been thought, even in adolescents with mildly elevated BP, and is, at least in the early stages, reversible [28] [29]. In recent years intensive research has been performed investigating the importance of the earliest indicators of target organ damage, which includes measurement of intima media thickness of the carotid artery, pulse wave velocity measurement of vessels, microalbuminuria [29]-[31]. Further research is needed in the field of early indicators of damage of target organs and early markers of cardiovascular risks, especially in the area of potential genetic factors [32].

\section{Prevention of Hypertension in Adolescent}

Without a doubt, the most important part of management of adolescents in terms of cardiovascular health is prevention. The measures of primary prevention are used to prevent the occurrence of cardiovascular disease through the reduction of known cardiovascular risk factors. Secondary prevention includes measures for the 


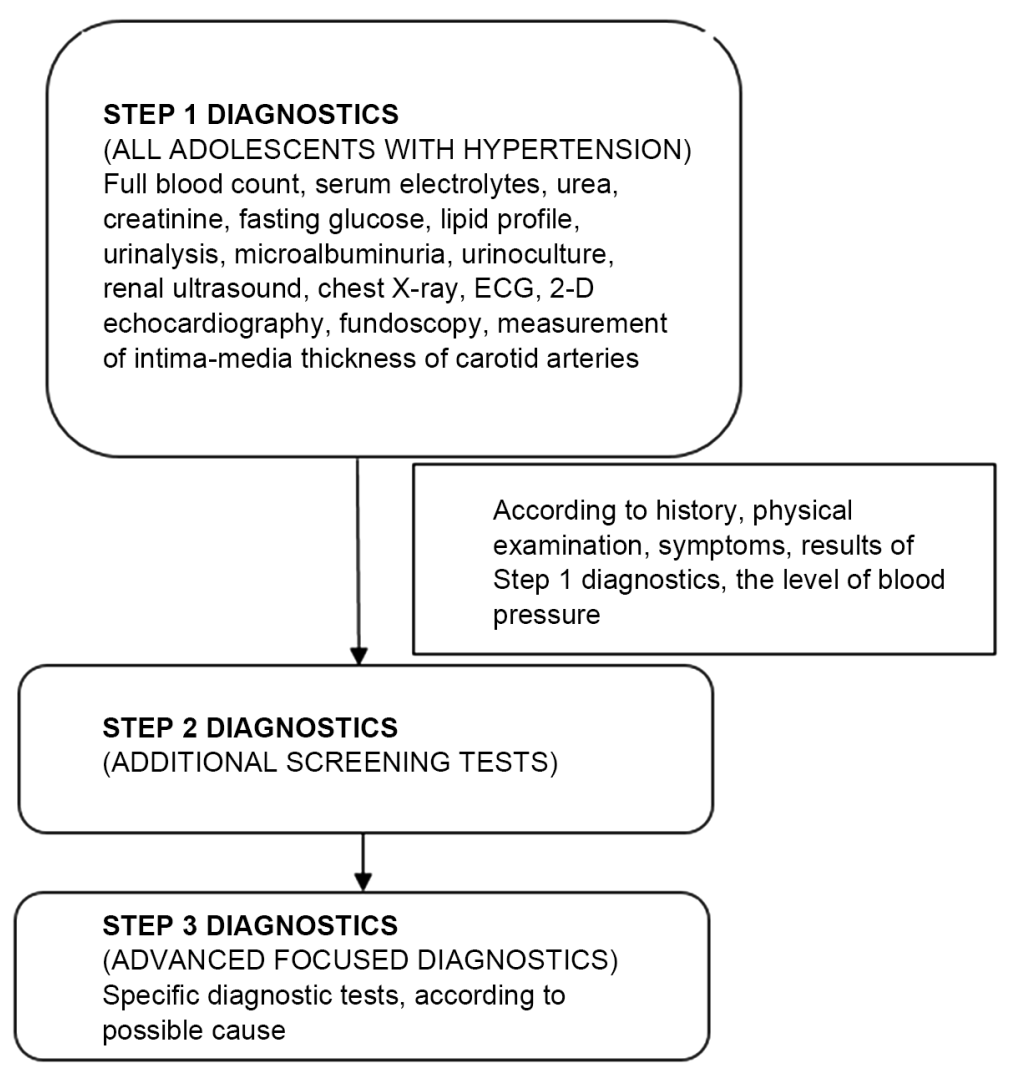

Figure 1. Diagnostics of adolescents with elevated blood pressure [12] [13].

early detection and treatment of preclinical changes and with that appropriately control the progression of the disease [15] [16]. In addition to primary and secondary prevention in recent times the importance of so-called primordial prevention has been increasingly recognized as a new important mechanism for improving cardiovascular health. The term refers to the way of maintaining normal levels of known cardiovascular risk factors, including the BP, from childhood to adulthood [15]. It is derived from the principles of a healthy lifestyle, which does not allow the occurrence of cardiovascular risk factors and as such represents the best way to lower cardiovascular risk [16]. Few recent research studies have shown that individuals who maintain an ideal profile of cardiovascular risk factors from youth to middle age, have significantly reduced risk of all cardiovascular events and a better quality of life in later life [33]. In addition to focus on maintaining good health, it is necessary to search for individuals with increased cardiovascular risks, which have, due to inappropriate lifestyle, genetic predisposition or diseases, a greater likelihood of early cardiovascular aging [34]. These clearly include adolescents with hypertension, especially adipose ones. After identification of adolescents at risk there is urgent need to initiate appropriate treatment and to follow-up them regularly. Better detection of young hypertensive patients is undoubtedly enabled by regular measurements of BP from the third year onwards, as well as by search for potential patients through regular visits to personal pediatricians, including adipose adolescents and those with a positive family history of cardiovascular disease [34]. It has to be stressed that cardiovascular prevention and active search for adolescents at risk are not only the task of health workers, but of the entire state and civil society [35]. Healthy lifestyle and self-care are the duties of each individual, but we must encourage them at all levels, in families, schools, local communities, relevant ministries, with the support of the public media [35]. Moreover, there is a need for a global approach to the problem of cardiovascular health with long-term goal to limit the cardiovascular disease epidemic [36]. Recently recommendations on the preservation of cardiovascular health by age and developmental pediatric groups have also been published [37].

\section{Treatment of Hypertension in Adolescent}

The main goal of the treatment of hypertension in adolescence is to reduce the cardiovascular risk associated 
with persistently elevated BP [38]. Rarely, emergency treatment is required due to very high values of BP and symptomatology. In this case, the use of short-acting intravenous antihypertensive agents is needed, with careful monitoring of the cardiovascular system, preferably in an intensive care unit [39] [40]. The basis of treatment represent non-pharmacological treatment measures, introduced in all patients, including those who require pharmacological treatment. Lifestyle change and a healthy lifestyle promotion with a healthy diet, improved quality of sleep, regular physical activity and limited sedentary activities represent the first line therapy [41] [42]. Dietary changes include a reduction in fat and cholesterol, especially saturated fat, reduction of the intake of soft drinks and fast food, increased intake of fresh fruits, vegetables and whole grains, quantitative restrictions of meals and drinks, limitation of discharging meals. Thus, randomized study DASH (Dietary Approaches to Stop Hypertension) in a group of adolescents with hypertension has shown, that the increase in fruit and vegetable intake and limitation of the fat intake was associated with a clear BP reduction [43]. The best results were achieved by a combination of modified diet and regular physical activity. It has also been shown that a moderate reduction in salt intake lowers the level of BP [44]. Further significant reduction of BP has been achieved by physical activity [45] [46]. At least 60 minutes of moderate to intensive physical activity daily are recommended as well as limitation of sedentary activities to less than two hours per day [37] [42].

In adolescents, the basis of treatment as a rule is non-pharmacological treatment. Indications for the introduction of drugs are symptomatic hypertension, presence of hypertensive target organ damage, secondary hypertension, hypertension of stage 2, presence of diabetes, persistent hypertension despite non-pharmacological measures [12]. Treatment algorithm is shown in Figure 2 [12]. At this point it should be noted that long-term consequences of untreated hypertension in otherwise healthy and asymptomatic adolescents are not known [47]. It is also not clear if there are some long-term effects of antihypertensive drugs on growth and development [11]. On the other hand, it has been proven that with the effective treatment hypertensive end-organ damage is reversible [48]. In recent years, quite a lot clinical research was performed also in children and adolescents on the efficacy and safety of antihypertensive drugs, as well as comparisons between different groups of antihypertensive medications [49]-[53]. Anyway, we still have the problem of the indications for use in small children [54] [55]. Drug classes with individual representatives, initial doses and maximum doses, are shown in Table 2 [12] [38] [56]. Among them, the most commonly used medications are those in the first five groups, in particular ACE inhibitors and calcium channel antagonists [14]. Dosage for adults should not be overcome [38] [56]. In some clinical situations, depending on the pathophysiological mechanism, a certain class of antihypertensive agent is preferably recommended (Table 3) [12]. The target value of BP also depends on the clinical condition (Table 4), although additional studies to confirm these values are needed [12]. Sometimes for BP regulation in adolescents more antihypertensive drugs are needed, while we prefer a combination with complementary mechanisms of action. In our hypertensive adolescents more drugs have been introduced in $15.8 \%$ of all patients, treated pharmacologically. The drugs were introduced in one third of investigated patients [57]. In overweight adolescents with

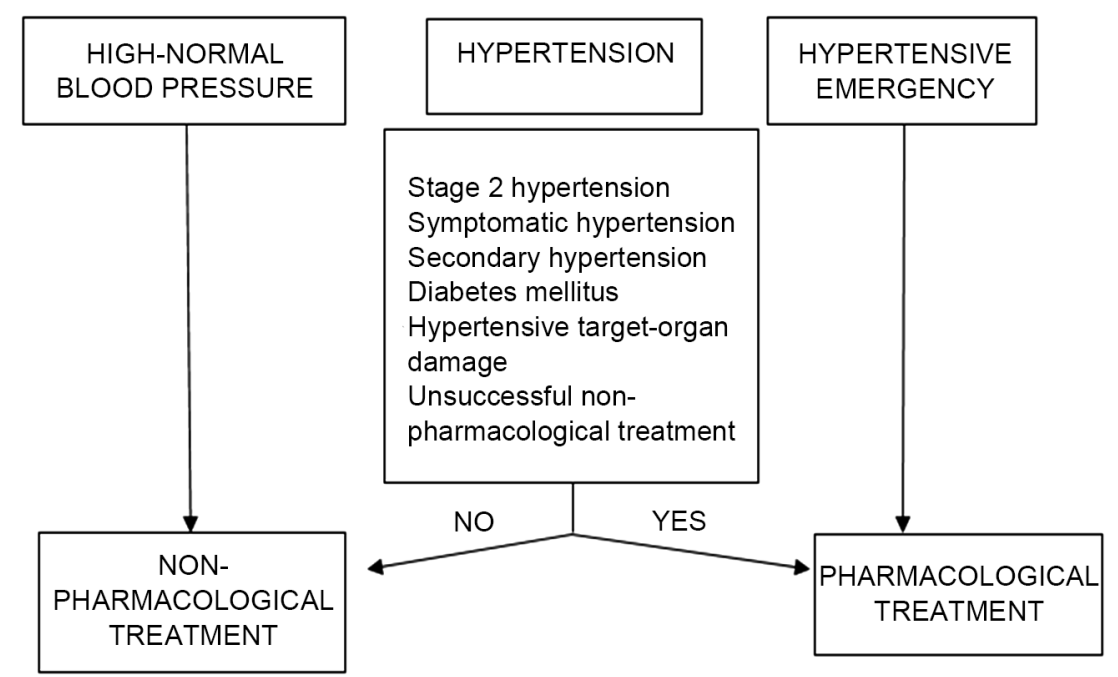

Figure 2. Treatment of child and adolescent with elevated blood pressure (adapted according to ref. [12]). 
Table 2. Classes and representatives of antihypertensive medications and doses for children and adolescents, according to weight, with maximum doses (adapted according to ref. [12] [38] and [56]).

\begin{tabular}{|c|c|c|c|c|}
\hline Class & Medication & Dose & Interval & Maximum dose \\
\hline Diuretics & $\begin{array}{l}\text { Amiloride } \\
\text { Chlorthalidone } \\
\text { Furosemide } \\
\text { Hydrochloro-thiazide } \\
\text { Chlorothiazide }\end{array}$ & $\begin{array}{c}0.4-0.6 \mathrm{mg} / \mathrm{kg} / \text { day } \\
0.3 \mathrm{mg} / \mathrm{kg} / \mathrm{day} \\
0.5-2.0 \mathrm{mg} / \mathrm{kg} / \mathrm{dose} \\
0.5-1.0 \mathrm{mg} / \mathrm{kg} / \text { day } \\
10 \mathrm{mg} / \mathrm{kg} / \text { day }\end{array}$ & $\begin{array}{l}\text { q.d. } \\
\text { q.d. } \\
\text { q.d.-b.d. } \\
\text { q.d.-b.d. } \\
\text { b.d. }\end{array}$ & $\begin{array}{c}20 \mathrm{mg} / \text { day } \\
50 \mathrm{mg} / \text { day } \\
6 \mathrm{mg} / \mathrm{kg} / \text { day } \\
50 \mathrm{mg} / \text { day } \\
1 \mathrm{~g} / \text { day }\end{array}$ \\
\hline Beta-adrenergic blockers & $\begin{array}{l}\text { Atenolol } \\
\text { Metoprolol } \\
\text { Propranolol } \\
\text { Bisoprolol }\end{array}$ & $\begin{array}{c}0.5-1.0 \mathrm{mg} / \mathrm{kg} / \text { day } \\
0.5-1.0 \mathrm{mg} / \mathrm{kg} / \text { day } \\
1.0 \mathrm{mg} / \mathrm{kg} / \mathrm{day} \\
0.2 \mathrm{mg} / \mathrm{kg} / \mathrm{day}\end{array}$ & $\begin{array}{l}\text { q.d.-b.d. } \\
\text { q.d. } \\
\text { b.d.-t.d. } \\
\text { q.d. }\end{array}$ & $\begin{array}{c}100 \mathrm{mg} / \text { day } \\
200 \mathrm{mg} / \text { day } \\
320 \mathrm{mg} / \text { day } \\
10 \mathrm{mg} / \text { day }\end{array}$ \\
\hline $\begin{array}{l}\text { Chalcium channel } \\
\text { antagonists }\end{array}$ & $\begin{array}{l}\text { Amlodipine } \\
\text { Felodipine } \\
\text { Nifedipine (ER) }\end{array}$ & $\begin{array}{c}0.06-0.3 \mathrm{mg} / \mathrm{kg} / \mathrm{day} \\
2.5 \mathrm{mg} / \mathrm{day} \\
0.25-0.50 \mathrm{mg} / \mathrm{kg} / \text { day }\end{array}$ & $\begin{array}{l}\text { q.d. } \\
\text { q.d. } \\
\text { q.d.-b.d. }\end{array}$ & $\begin{array}{c}10 \mathrm{mg} / \text { day } \\
10 \mathrm{mg} / \text { day } \\
120 \mathrm{mg} / \text { day }\end{array}$ \\
\hline $\begin{array}{l}\text { Angiotensin-converting } \\
\text { enzyme inhibitors }\end{array}$ & $\begin{array}{c}\text { Captopril } \\
\text { Enalapril } \\
\text { Fosinopril } \\
\text { Lisinopril } \\
\text { Ramipril }\end{array}$ & $\begin{array}{c}0.3-0.5 \mathrm{mg} / \mathrm{kg} / \mathrm{day} \\
0.08-0.60 \mathrm{mg} / \mathrm{kg} / \mathrm{day} \\
0.1-0.6 \mathrm{mg} / \mathrm{kg} / \mathrm{day} \\
0.08-0.60 \mathrm{mg} / \mathrm{kg} / \text { day } \\
2.5 \mathrm{mg} / \text { day }\end{array}$ & $\begin{array}{l}\text { b.d.-t.d. } \\
\text { q.d. } \\
\text { q.d. } \\
\text { q.d. } \\
\text { q.d. }\end{array}$ & $\begin{array}{l}450 \mathrm{mg} / \text { day } \\
40 \mathrm{mg} / \text { day } \\
40 \mathrm{mg} / \text { day } \\
40 \mathrm{mg} / \text { day } \\
20 \mathrm{mg} / \text { day }\end{array}$ \\
\hline $\begin{array}{l}\text { Angiotensin-receptor } \\
\text { blockers }\end{array}$ & $\begin{array}{l}\text { Candesartan } \\
\text { Irbesartan } \\
\text { Losartan } \\
\text { Valsartan }\end{array}$ & $\begin{array}{c}0.16-0.50 \mathrm{mg} / \mathrm{kg} / \text { day } \\
75-150 \mathrm{mg} / \mathrm{day} \\
0.75-1.44 \mathrm{mg} / \mathrm{kg} / \text { day } \\
2 \mathrm{mg} / \mathrm{kg} / \mathrm{day}\end{array}$ & $\begin{array}{l}\text { q.d. } \\
\text { q.d. } \\
\text { q.d. } \\
\text { q.d. }\end{array}$ & $\begin{array}{l}32 \mathrm{mg} / \text { day } \\
300 \mathrm{mg} / \text { day } \\
100 \mathrm{mg} / \text { day } \\
320 \mathrm{mg} / \text { day }\end{array}$ \\
\hline $\begin{array}{l}\text { Alpha- and beta-adrenergic } \\
\text { blockers }\end{array}$ & $\begin{array}{l}\text { Labetalol } \\
\text { Carvedilol }\end{array}$ & $\begin{array}{l}2-3 \mathrm{mg} / \mathrm{kg} / \text { day } \\
0.1 \mathrm{mg} / \mathrm{kg} / \text { dose }\end{array}$ & $\begin{array}{l}\text { b.d. } \\
\text { b.d. }\end{array}$ & $\begin{array}{l}1.2 \mathrm{~g} / \text { day } \\
50 \mathrm{mg} / \text { day }\end{array}$ \\
\hline $\begin{array}{l}\text { Aldosterone-receptor } \\
\text { blockers }\end{array}$ & $\begin{array}{l}\text { Eplerenone } \\
\text { Spironolactone }\end{array}$ & $\begin{array}{c}25-50 \mathrm{mg} / \text { day } \\
1 \mathrm{mg} / \mathrm{kg} / \text { day }\end{array}$ & $\begin{array}{l}\text { q.d.-b.d. } \\
\text { q.d.-b.d. }\end{array}$ & $\begin{array}{l}100 \mathrm{mg} / \text { day } \\
100 \mathrm{mg} / \text { day }\end{array}$ \\
\hline Central alpha-agonists & $\begin{array}{l}\text { Clonidine } \\
\text { Methyldopa }\end{array}$ & $\begin{array}{c}5-10 \mu \mathrm{g} / \mathrm{kg} / \text { day } \\
5 \mathrm{mg} / \mathrm{kg} / \text { day }\end{array}$ & $\begin{array}{l}\text { b.d.-t.d. } \\
\text { b.d.-f.d. }\end{array}$ & $\begin{array}{l}0.9 \mathrm{mg} / \text { day } \\
3 \text { g/day }\end{array}$ \\
\hline $\begin{array}{l}\text { Peripheral alpha-adrenergic } \\
\text { blockers }\end{array}$ & $\begin{array}{l}\text { Doxazosin } \\
\text { Prazosin } \\
\text { Terazosin }\end{array}$ & $\begin{array}{c}1 \mathrm{mg} / \text { day } \\
0.05-0.1 \mathrm{mg} / \mathrm{kg} / \text { day } \\
1 \mathrm{mg} / \text { day }\end{array}$ & $\begin{array}{l}\text { f.d. } \\
\text { t.d. } \\
\text { q.d. }\end{array}$ & $\begin{array}{c}4 \mathrm{mg} / \text { day } \\
0.5 \mathrm{mg} / \mathrm{kg} / \text { day } \\
20 \mathrm{mg} / \text { day }\end{array}$ \\
\hline Vasodilators & $\begin{array}{l}\text { Hydralazine } \\
\text { Minoxidil }\end{array}$ & $\begin{array}{c}0.25 \mathrm{mg} / \mathrm{kg} / \text { dose } \\
0.1-0.2 \mathrm{mg} / \mathrm{kg} / \text { day }\end{array}$ & $\begin{array}{l}\text { t.d.-f.d } \\
\text { b.d.-t.d. }\end{array}$ & $\begin{array}{l}200 \mathrm{mg} / \text { day } \\
50 \mathrm{mg} / \text { day }\end{array}$ \\
\hline
\end{tabular}

q.d.—once daily, b.d.—twice daily, t.d.—three times daily, f.d.—four times daily, ER—extended release.

Table 3. First choice of antihypertensive medication in adolescent with specific disease and hypertension [12].

\begin{tabular}{cc}
\hline Clinical condition & First choice of antihypertensive medication \\
\hline Without any other disease & Drug from any class \\
Chronic kidney disease & ACEI/ARB \\
Migraine & Beta blockers, calcium channel antagonists \\
Obesity & ACEI \\
Coarctation of aorta & Beta blockers \\
Diabetes mellitus & ACEI/ARB \\
Chronic kidney failure & Diuretics \\
Hyperaldosteronism & Diuretics \\
Congestive heart failure & Beta blockers, ACEI/ARB, loop-acting diuretics \\
Kidney transplantation & Calcium channel antagonists \\
\hline
\end{tabular}

ACEI—angiotensin-converting enzyme inhibitors, ARB—angiotensin-receptor blockers. 
Table 4. Blood pressure targets in different groups of patients [12].

\begin{tabular}{cc}
\hline \multicolumn{1}{c}{ Patients } & \multicolumn{1}{c}{ Blood pressure target } \\
\hline $\begin{array}{c}\text { Uncomplicated essential hypertension } \\
\text { Secondary hypertension, diabetes mellitus, } \\
\text { hypertensive target-organ damage }\end{array}$ & $<95^{\text {th }}$ percentile for sex, age and height \\
Chronic kidney disease without proteinuria & $<75^{\text {th }}$ percentile for sex, age and height \\
Chronic kidney disease with proteinuria & $<50^{\text {th }}$ percentile for sex, age and height \\
\hline
\end{tabular}

successful non-pharmacological treatment withdrawal of medications is possible ("step-down" treatment). At that time the reversibility of changes in hypertensive target organ damage has to be taken into account [12]. Furthermore, it has been found out that improved therapies in children have potential for preventing or ameliorating early cardiovascular disease [58].

At the end, the problem of poor treatment compliance of some young people has to be mentioned, especially for non-pharmacological treatments. Even medications are often omitted [59] [60]. Therefore, in adolescents follow-up is of utmost importance, with continuous education, interpretation of the nature of the disease, its long-term consequences, the necessity of treatment [61]. They need to be motivated for treatment, continuously educated and promoted for a healthy lifestyle. It is important to work with the entire family.

\section{Conclusion}

Hypertension, one of the major cardiovascular risk factors, often also occurs in adolescents. With the introduction of routine measurement of BP of healthy children in pediatric healthcare and the active search for high-risk groups, patients with asymptomatic disease can be detected and appropriately diagnosed and treated, which has a long-term positive effects on cardiovascular health. The preventive action is equally important, in particular with the ever-increasing occurrence of obesity and related diseases. Treatment of adolescents is primarily nonpharmacological, but sometimes also requires the introduction of drugs.

\section{References}

[1] May, A.L., Kuklina, E.V. and Yoon, P.W. (2012) Prevalence of Cardiovascular Disease Risk Factors among US Adolescents, 1999-2008. Pediatrics, 129, 1035-1041. http://dx.doi.org/10.1542/peds.2011-1082

[2] Flynn, J. (2012) The Changing Face of Pediatric Hypertension in the Era of the Childhood Obesity Epidemic. Pediatric Nephrology, 28, 1059-1066. http://dx.doi.org/10.1007/s00467-012-2344-0

[3] Moore, W.E., Stephens, A., Wilson, T., Wilson, W. and Eichner, J.E. (2006) Body Mass Index and Blood Pressure Screening in a Rural Public School System: the Healthy Kids Project. Preventing Chronic Disease, 3, 1-10. http://www.cdc.gov/pcd/issues/2006/oct/05_0236.htm

[4] Falkner, B., Gidding, S.S., Portman, R. and Rosner, B. (2008) Blood Pressure Variability and Classification of Prehypertension and Hypertension in Adolescence. Pediatrics, 122, 238-242. http://dx.doi.org/10.1542/peds.2007-2776

[5] Marčun Varda, N. (2006) The Role of Some Genetic Factors in the Development of Essential Hypertension in Children and Young Adults. Ph.D. Dissertation, Medical Faculty Ljubljana, Ljubljana.

[6] Sorof, J.M., Lai, D., Turner, J., Poffenburger, T. and Portman, R.J. (2004) Overweight, Ethnicity, and the Prevalence of Hypertenison in School-Aged Children. Pediatrics, 113, 475-482. http://dx.doi.org/10.1542/peds.113.3.475

[7] Chen, X. and Wang, Y. (2008) Tracking of Blood Pressure from Childhood to Adulthood: A Systematic Review and Meta-Regression Analysis. Circulation, 117, 3171-3180. http://dx.doi.org/10.1161/CIRCULATIONAHA.107.730366

[8] Lawes, C.M., Vander Hoorn, S., Law, M.R., Elliott, P., MacMahon, S. and Rodgers, A. (2006) Blood Pressure and the Global Burden of Disease 2000. Part II: Estimates of Attributable Burden. Journal of Hypertension, 24, 423-430. http://dx.doi.org/10.1097/01.hjh.0000209973.67746.f0

[9] Franks, P.W., Hanson, R.L., Knowler, W.C., Sievers, M.L., Bennett, P.H. and Looker, H.C. (2010) Childhood Obesity, Other Cardiovascular Risk Factors, and Premature Death. New England Journal of Medicine, 362, 485-493. http://dx.doi.org/10.1056/NEJMoa0904130

[10] Sundstrom, J., Neovius, M., Tynelius, P. and Rasmussen, F. (2011) Association of Blood Pressure in Late Adolescence with Subsequent Mortality: Cohort Study of Swedish Male Conscripts. British Medical Journal, 342, d643. 
http://dx.doi.org/10.1136/bmj.d643

[11] National High Blood Pressure Education Program Working Group on High Blood Pressure in Children and Adolescents (2004) The Fourth Report on the Diagnosis, Evaluation, and Treatment of High Blood Pressure in Children and Adolescents. Pediatrics, 144, 555-576.

[12] Lurbe, E., Cifkova, R., Cruickshank Kennedy, J., Dillon, M.J., Ferreira, I., Invitti, C., et al. (2009) Management of High Blood Pressure in Children and Adolescents: Recommendations of the European Society of Hypertension. Journal of Hypertension, 27, 1719-1742. http://dx.doi.org/10.1097/HJH.0b013e32832f4f6b

[13] Varda, N.M. and Gregorič, A. (2005) A Diagnostic Approach for the Child with Hypertension. Pediatric Nephrology, 20, 499-506. http://dx.doi.org/10.1007/s00467-004-1737-0

[14] Woroniecki, R.P. and Flynn, J.T. (2005) How Are Hypertensive Children Evaluated and Managed? A Survey of North American Pediatric Nephrologists. Pediatric Nephrology, 20, 791-797. http://dx.doi.org/10.1007/s00467-004-1804-6

[15] Capwell, S. and Lloyd-Jones, D.M. (2010) Optimal Cardiovascular Prevention Strategies for the 21st Century. JAMA, 304, 2057-2058. http://dx.doi.org/10.1001/jama.2010.1641

[16] Kones, R. (2011) Primary Prevention of Coronary Heart Disease: Integration of New Data, Evolving Views, Revised Goals, and Role of Rosuvastatin in Management. A Comprehensive Survey. Drug Design, Development and Therapy, 5, 325-380. http://dx.doi.org/10.2147/DDDT.S14934

[17] Dabl Educational Trust (2016) Blood Pressure Monitors—Validations, Papers and Reviews. http://www.dableducational.org/

[18] Neuhauser, H.K., Thamm, M., Ellert, U., Hense, H.W. and Rosario, A.S. (2011) Blood Pressure Percentiles by Age and Height from Nonoverweight Children and Adolescents in Germany. Pediatrics, 127, e978-e988. http://dx.doi.org/10.1542/peds.2010-1290

[19] Kułaga, Z., Litwin, M., Grajda, A., Kułaga, K., Gurzkowska, B., Góźdź, M., et al. and OLAF Study Group (2012) Oscillometric Blood Pressure Percentiles for Polish Normal-Weight School-Aged Children and Adolescents. Journal of Hypertension, 30, 1942-1954. http://dx.doi.org/10.1097/HJH.0b013e328356abad

[20] Mancia, G., Fagard, R., Narkiewicz, K., Redán, J., Zanchetti, A., Böhm, M., et al. (2013) 2013 Practice Guidelines for the Management of Arterial Hypertension of the European Society of Hypertension (ESH) and the European Society of Cardiology (ESC): ESH/ESC Task Force for the Management of Arterial Hypertension. Journal of Hypertension, 31 , 1925-1938. http://dx.doi.org/10.1097/HJH.0b013e328364ca4c

[21] Symonides, B., Jędrusik, P., Artyszuk, L., Gryboś, A., Dziliński, P. and Gaciong, Z. (2010) Different Diagnostic Criteria Significantly Affect the Rates of Hypertension in 18-Year-Old High School Students. Archives of Medical Science, 6, 689-694. http://dx.doi.org/10.5114/aoms.2010.17082

[22] Simckes, A.M., Srivastava, T. and Alon, U.S. (2002) Ambulatory Blood Pressure Monitoring in Children and Adolescents. Clinical Pediatrics, 41, 549-564. http://dx.doi.org/10.1177/000992280204100801

[23] Soergl, M., Kirschstein, M., Busch, C., Danne, T., Gellermann, J., Holl, R., et al. (1997) Oscillometric Twenty-FourHour Ambulatory Blood Pressure Values in Healthy Children and Adolescents: A Multicenter Trial Including 1141 Subjects. Journal of Pediatrics, 130, 178-184. http://dx.doi.org/10.1016/S0022-3476(97)70340-8

[24] Metoki, H., Ohkubo, T., Kikuya, M., Asayama, K., Obara, T., Hara, A., et al. (2006) Prognostic Significance of Night-Time, Early Morning, and Daytime Blood Pressures on the Risk of Cerebrovascular and Cardiovascular Mortality: The Ohasama Study. Journal of Hypertension, 24, 1841-1848. http://dx.doi.org/10.1097/01.hjh.0000242409.65783.fb

[25] Belsha, C.W. (1999) Ambulatory Blood Pressure Monitoring and Hypertensive Target-Organ Damage in Children. Blood Pressure Monitoring, 4, 161-164.

[26] Marčun Varda, N. (2012) Diagnostic Evaluation of the Child and Adolescent with Hypertension. Slovenska Pediatrija, 19, 276-285.

[27] Litwin, M., Niemirska, A., Sladowska-Kozlowska, J., Wierzbicka, A., Janas, R., Wawer, Z.T., et al. (2010) Regression of Target Organ Damage in Children and Adolescents with Primary Hypertension. Pediatric Nephrology, 25, 24892499. http://dx.doi.org/10.1007/s00467-010-1626-7

[28] Sladowska-Kozłowska, J., Litwin, M., Niemirska, A., Wierzbicka, A., Wawer, Z.T. and Janas, R. (2011) Change in Left Ventricular Geometry during Antihypertensive Treatment in Children with Primary Hypertension. Pediatric Nephrology, 26, 2201-2209. http://dx.doi.org/10.1007/s00467-011-1916-8

[29] Assadi, F. (2007) Effect of Microalbuminuria Lowering on Regression of Left Ventricular Hypertrophy in Children and Adolescents with Essential Hypertension. Pediatric Cardiology, 28, 27-33.

http://dx.doi.org/10.1007/s00246-006-1390-4

[30] Lande, M.B., Carson, N.L., Roy, J. and Meagher, C.C. (2006) Effects of Childhood Primary Hypertension on Carotid 
Intima Media Thickness: A Matched Controlled Study.Hypertension, 48, 40-44. http://dx.doi.org/10.1161/01.HYP.0000227029.10536.e8

[31] Litwin, M., Trelewicz, J., Wawer, Z., Antoniewicz, J., Wierzbicka, A., Rajszys, P., et al. (2004) Intima-Media Thickness and Arterial Elasticity in Hypertensive Children: Controlled Study. Pediatric Nephrology, 19, 767-774. http://dx.doi.org/10.1007/s00467-004-1480-6

[32] Urbina, E.M., Williams, R.V., Alpert, B.S., Collins, R.T., Daniels, S.R., Hayman, L., et al. (2009) Noninvasive Assessment of Subclinical Atherosclerosis in Children and Adolescents: Recommendations for Standard Assessment for Clinical Research: A Scientific Statement from the American Heart Association. Hypertension, 54, 919-950. http://dx.doi.org/10.1161/HYPERTENSIONAHA.109.192639

[33] Lloyd-Jones, D.M., Hong, Y., Labarthe, D., Mozaffarian, D., Appel, L.J., Van Horn, L., et al. (2010) American Heart Association Strategic Planning Task Force and Statistics Committee. Defining and Setting National Goals for Cardiovascular Health Promotion and Disease Reduction: The American Heart Association's Strategic Impact Goal through 2020 and beyond. Circulation, 121, 586-613. http://dx.doi.org/10.1161/CIRCULATIONAHA.109.192703

[34] Hong, Y.M. (2010) Atherosclerotic Cardiovascular Disease Beginning in Childhood. Korean Circulation Journal, 40, 1-9. http://dx.doi.org/10.4070/kcj.2010.40.1.1

[35] Falkner, B., Lurbe, E. and Schaefer, F. (2010) High Blood Pressure in Children: Clinical and Health Policy Implications. Journal of Clinical Hypertension, 12, 261-276. http://dx.doi.org/10.1111/j.1751-7176.2009.00245.X

[36] Kavey, R.E.W., Daniels, S.R. and Flynn, J.T. (2010) Management of High Blood Pressure in Children and Adolescents. Cardiology Clinics, 28, 597-607. http://dx.doi.org/10.1016/j.ccl.2010.07.004

[37] Kavey, R.E.W., Simons-Morton, D. and Jesus, J.M. (2011) Expert Panel on Integrated Guidelines for Cardiovascular Health and Risk Reduction in Children and Adolescents: Summary Report. Pediatrics, 128, S213-S256. http://dx.doi.org/10.1542/peds.2009-2107C

[38] Lande, M.B. and Flynn, J.T. (2009) Treatment of Hypertension in Children and Adolescents. Pediatric Nephrology, 24, 1939-1949. http://dx.doi.org/10.1007/s00467-007-0573-4

[39] Flynn, J.T. and Tullus, K. (2009) Severe Hypertension in Children and Adolescents: Pathophysiology and Treatment. Pediatric Nephrology, 24, 1101-1112. http://dx.doi.org/10.1007/s00467-008-1000-1

[40] Varon, J. (2008) Treatment of Acute Severe Hypertension. Drugs, 68, 283-297. http://dx.doi.org/10.2165/00003495-200868030-00003

[41] Roberts, C.K. and Barnard, R.J. (2005) Effects of Exercise and Diet on Chronic Disease. Journal of Applied Physiology, 98, 3-30. http://dx.doi.org/10.1152/japplphysiol.00852.2004

[42] Williams, C.L., Hayman, L.L., Daniels, S.R., Robinson, T.N., Steinberger, J., Paridon, S., et al. (2002) Cardiovascular Health in Childhood. A Statement for Health Professionals from the Committee on Atherosclerosis, Hypertension, and Obesity in the Young (AHOY) of the Council on Cardiovascular Disease in the Young. American Heart Association, Circulation, 106, 143-160. http://dx.doi.org/10.1161/01.cir.0000019555.61092.9e

[43] Couch, S.C., Saelens, B.E., Levin, L., Dart, K., Falciglia, G. and Daniels, S.R. (2008) The Efficacy of a Clinic-Based Behavioral Nutrition Intervention Emphasizing a DASH-Type Diet for Adolescents with Elevated Blood Pressure. Journal of Pediatrics, 152, 494-501. http://dx.doi.org/10.1016/j.jpeds.2007.09.022

[44] He, F.J. and MacGregor, G.A. (2006) Importance of Salt in Determining Blood Pressure in Children: Meta-Analysis of Controlled Trials. Hypertension, 48, 861-869. http://dx.doi.org/10.1161/01.HYP.0000245672.27270.4a

[45] Kelley, G.A., Kelley, K.S. and Tran, Z.V. (2003) The Effects of Exercise on Resting Blood Pressure in Children and Adolescents: A Meta-Analysis of Randomized Controlled Trials. Preventive Cardiology, 6, 8-16. http://dx.doi.org/10.1111/j.1520-037X.2003.01224.X

[46] Rocchini, A.P., Katch, V., Anderson, J., Hinderliter, J., Becque, D., Martin, M. and Marks, C. (1988) Blood Pressure in Obese Adolescents: Effect of Weight Loss. Pediatrics, 82, 16-23.

[47] Flynn, J.T. (2009) Hypertension in the Young: Epidemiology, Sequelae and Therapy. Nephrology Dialysis Transplantation, 24, 370-375. http://dx.doi.org/10.1093/ndt/gfn597

[48] Kupferman, J.C., Paterno, K., Mahgerefteh, J., Pagala, M., Golden, M., Lytrivi, I.D., et al. (2010) Improvement of Left Ventricular Mass with Antihypertensive Therapy in Children with Hypertension. Pediatric Nephrology, 25, 1513-1518. http://dx.doi.org/10.1007/s00467-010-1511-4

[49] Flynn, J.T. (2011) Not Ready for Prime Time: Aliskiren for Treatment of Hypertension or Proteinuria in Children. Pediatric Nephrology, 26, 491-492. http://dx.doi.org/10.1007/s00467-010-1726-4

[50] Herder, S.D., Weber, E., Winkemann, A., Herder, E. and Morck, H. (2010) Efficacy and Safety of Angiotensin II Receptor Type 1 Antagonists in Children and Adolescents. Pediatric Nephrology, 25, 801-811.

http://dx.doi.org/10.1007/s00467-009-1346-z 
[51] Li, J.S., Flynn, J.T., Portman, R., Davis, I., Ogawa, M., Shi, H., Pressler, M.L., et al. (2010) The Efficacy and Safety of the Novel Aldosterone Antagonist Eplerenone in Children with Hypertension: A Randomized, Double-Blind, DoseResponse Study. Journal of Pediatrics, 157, 282-287. http://dx.doi.org/10.1016/j.jpeds.2010.02.042

[52] Schaefer, F., Litwin, M., Zachwieja, J., Zurowska, A., Turi, S., Grosso, A., et al. (2011) Efficacy and Safety of Valsartan Compared to Enalapril in Hypertensive Children. A 12-Week, Randomized, Double-Blind, Parallel-Group Study. Journal of Hypertension, 29, 2484-2490. http://dx.doi.org/10.1097/HJH.0b013e32834c625c

[53] Chaturvedi, S., Lipszyc, D.H., Licht, C., Craig, J.C. and Parekh, R.S. (2014) Cochrane in Context: Pharmacological Interventions for Hypertension in Children. Evidence Based Child Health, 9, 581-583. http://dx.doi.org/10.1002/ebch.1975

[54] Flynn, J.T., Meyers, K.E., Neto, J.P., de Paula, M.R., Zurowska, A., Bagga, A., et al. (2008) Efficacy and Safety of the Angiotensin Receptor Blocker Valsartan in Children with Hypertension Aged 1 to 5 Years. Hypertension, 52, 222-228. http://dx.doi.org/10.1161/HYPERTENSIONAHA.108.111054

[55] Schaefer, F., van de Walle, J., Zurowska, A., Gimpel, C., van Hoeck, K., Drozdz, D., et al. and Candesartan in Children with Hypertension Investigators (2010) Efficacy, Safety and Pharmacokinetics of Candesartan Cilexetil in Hypertensive Children from 1 to Less than 6 Years of Age. Journal of Hypertension, 28, 1083-1090. http://dx.doi.org/10.1097/HJH.0b013e328336b86b

[56] Flynn, J.T. (2011) Management of Hypertension in the Young: Role of Antihypertensive Medications. Journal of Cardiovascular Pharmacology, 58, 111-120. http://dx.doi.org/10.1097/FJC.0b013e31820d1b89

[57] Marčun Varda, N. and Gregorič, A. (2011) Hypertensive Target Organ Damage and Antihypertensive Treatment in Children with Essential Hypertension. Pediatric Nephrology, 26, 1726.

[58] Santi, M., Simonetti, B.G., Leoni-Foglia, C.F., Bianchetti, M.G. and Simonetti, G.D. (2015) Arterial Hypertension in Children. Current Opinion in Cardiology, 30, 403-410. http://dx.doi.org/10.1097/HCO.0000000000000191

[59] Osterberg, L. and Blaschke, T. (2005) Adherence to Medication. New England Journal of Medicine, 353, 487-497. http://dx.doi.org/10.1056/NEJMra050100

[60] Eakin, M.N., Brady, T., Kandasamy, V., Fivush, B. and Riekert, K.A. (2013) Disparities in Antihypertensive Medication Adherence in Adolescents. Pediatric Nephrology, 28, 1267-1273. http://dx.doi.org/10.1007/s00467-013-2455-2

[61] Rao, G. (2016) Diagnosis, Epidemiology, and Management of Hypertension in Children. Pediatrics, 138, e20153616. http://dx.doi.org/10.1542/peds.2015-3616

\section{Submit or recommend next manuscript to SCIRP and we will provide best service for you:}

Accepting pre-submission inquiries through Email, Facebook, LinkedIn, Twitter, etc.

A wide selection of journals (inclusive of 9 subjects, more than 200 journals)

Providing 24-hour high-quality service

User-friendly online submission system

Fair and swift peer-review system

Efficient typesetting and proofreading procedure

Display of the result of downloads and visits, as well as the number of cited articles

Maximum dissemination of your research work

Submit your manuscript at: http://papersubmission.scirp.org/ 